\title{
ЗВИВИСТІСТЬ ВІНЦЕВИХ АРТЕРІЙ В ДІАГНОСТИЦІ ПОРУШЕНЬ КОРОНАРНОЇ ГЕМОДИНАМІКИ
}

\author{
Є. О. Лебедєва ${ }^{1}$, М. М. Груша², С. М. Фанта ${ }^{1}$ \\ ${ }^{1}$ Національний інститут серцево-судинної хірургії імені М. М. Амосова НАМН України, м. Київ \\ ${ }^{2}$ Національний медичний університет імені О. О. Богомольця МОЗ України, м. Київ

\section{TORTUOSITY OF CORONARY ARTERIES IN DIAGNOSIS OF DISORDERS OF CORONARY HEMODYNAMICS}

\author{
E. O. Lebedeva ${ }^{1}$, M. M. Grusha ${ }^{2}$, S. M. Fanta ${ }^{1}$ \\ ${ }^{1}$ Amosov National Institute of Cardio-Vascular Surgery, Kyiv \\ ${ }^{2}$ Bogomolets National Medical University, Kyiv
}

\section{Реферат}

Обговорене діагностичне значення звивистості вінцевих артерій (ВА), її прогностична роль у виникненні хронічної ішемії міокарда, гострого порушення коронарного кровообігу та ішемічної хвороби серця (IXC) у пацієнтів без ангіографічних ознак атеросклеросклерозу (АС) стінки судин.

Мета дослідження: вивчення ролі звивистої конфігурації ВА в порушенні коронарного кровообігу.

Матеріали і методи. У дослідження включені 816 пацієнтів без змін конфігурації ВА і 588 - у яких виявлено звивистість ВА. Обстеження проводили з використанням загальноклінічних методів дослідження, електрокардіографії, ехокардіограффії (ЕХО-КГ), велоергометрії, коронаровентрикулографії (КВГ), стрес-векторехокардіографії (стрес-ВЕХО-КГ).

Результати. У пацієнтів з звивистими ВА, за відсутності ангіографічних ознак їх гемодинамічно значущого стенозу, виявляли типовий больовий синдром, клінічні ознаки стенокардії напруження та хронічної недостатності кровообігу. У пацієнтів 3 ангіографрічними ознаками гемодинамічно значущого стенозу звивистість ВА зумовлювала збільшення частоти виникнення аневризми лівого шлуночка.

Висновки. Звивистість ВА є фактором, здатним спричинити порушення перфузії міокарда, що створює підґрунтя для несприятливого прогнозу перебігу IXC, незалежно від наявності AC BA.

Ключові слова: ішемічна хвороба серця; звивистість вінцевих артерій; порушення коронарної гемодинаміки.

\section{Abstract}

Diagnostic significance of the coronary arteries tortuosity, its prognostic role in the chronic myocardial ischemia, an acute disorder of coronary blood circulation and the ischemic heart disease occurrence in patients without angiographic signs of atherosclerosis of vascular walls was discussed.

Objective. Studying of a role of tortuosity in the coronary arteries configuration in disorder of coronary blood circulation.

Materials and methods. In the investigation there were included 816 patients without changes in the coronary arteries configuration and 588 - in whom tortuosity of coronary arteries was revealed. Examination was conducted, using general clinical methods of investigation, electrocardiography, echocardiography, veloergometry, coronaroventriculography, stress-vectorechocardiography.

Results. In patients with tortuosity of coronary arteries, while absence of angiographic signs of their hemodynamically significant stenosis, a typical pain syndrome, clinical signs of angina pectoris and chronic insufficiency of blood circulation are present. In patients with angiographic signs of hemodynamically significant stenosis the coronary arteries tortuosity caused enhancement of the occurrence rate of the left ventricle aneurysm.

Conclusion. Tortuosity of coronary arteries constitutes a factor, capable to cause a disorder of myocardial perfusion, what creates a background for unfavorable prognosis of the ischemic heart disease course, not depending from presence of coronary arteries atherosclerosis.

Keywords: ischemic heart disease; tortuosity of coronary vessels; disorder of coronary hemodynamics.

Виникнення ішемії міокарда і стенокардії, відповідно до сучасної патофізіологічної моделі перебігу хронічної IXC, передусім, зумовлене формування гемодинамічно значущого стенозу ВА. Для встановлення діагнозу в клінічній практиці проводять прямий причинно-наслідковий зв'язок лише між обструктивним AC BA та IXC. Як наслідок, основну увагу при лікуванні таких станів спрямовують на визначення локалізації у ВА гемодинамічно значущої атеросклеротичної бляшки, усунення стенозу, застосування статинів або інших препаратів. Такий підхід створює шаблонність в діагностиці i, незважаючи на наявність у пацієнта клінічних проявів ішемії міокарда, до заперечення діагнозу IXC за відсутності ангіографічних ознак гемодинамічно значущого атеросклеротичного ураження стінки судин.

Діагностичні заходи концентруються на виявленні гемодинамічно значущого атеросклеротично- го ураження ВА та визначенні тяжкості коронарного АС, залежно від чого обирають тактику лікування та профілактики IXC. Водночас, відсутність стенозуючих атеросклеротичних змін ВА у хворих з звивистими ВА кардіологи помилково сприймають як ознаку сприятливого загального прогнозу.

Це може стати причиною відмови від заходів вторинної профілактики IXC та диспансерного спостереження таких пацієнтів. 
Розподіл пацієнтів залежно від ступеня атеросклеротичного ураження та конфігурації ВА за клінічними ознаками

\begin{tabular}{|c|c|c|c|c|c|c|c|c|}
\hline \multirow{3}{*}{ Показник } & \multicolumn{8}{|c|}{ Величина показника в групах } \\
\hline & \multicolumn{2}{|c|}{$1-\bar{n}(n=252)$} & \multicolumn{2}{|c|}{$2-\breve{n}(n=92)$} & \multicolumn{2}{|c|}{$3-\breve{n}(n=244)$} & \multicolumn{2}{|c|}{$4-\bar{n}(n=816)$} \\
\hline & абс. & $\%$ & абс. & $\%$ & абс. & $\%$ & абс. & $\%$ \\
\hline CH ФК2 & 120 & 47,6 & 20 & 21,7 & 24 & 9,8 & 72 & 8,8 \\
\hline $\mathrm{CH}$ ФКЗ & 124 & 49,2 & 52 & 56,5 & 168 & 68,9 & 632 & 77,5 \\
\hline CH ФK4 & - & - & 4 & 4,4 & 12 & 4,9 & 16 & 2,0 \\
\hline ХНК I стадії & 196 & 77,8 & 64 & 69,6 & 180 & 73,8 & 580 & 71,1 \\
\hline XНК II (А, Б) стадії & 32 & 12,7 & 24 & 26,1 & 60 & 24,6 & 224 & 27,5 \\
\hline
\end{tabular}

Досвід використання такого діагностично-лікувального протоколу під час надання спеціалізованої медичної допомоги дає підстави вважати, що встановлення прямого зв'язку лише між ішемією міокарда і атеросклеротичним ураженням стінки судин є занадто спрощеним поглядом на перебіг хронічної IXC. У численних дослідженнях наведені докази багатофакторності патофізіологічного процесу ураження ВА, в якому АС є лише одним з провідних елементів. До них також належать порушення мікроциркуляції, запалення, ендотеліальна дисфункція, тромбоз тощо, а ішемія міокарда може виникати як за наявності, так і відсутності AC BA [1]. За сучасними уявленнями, однією 3 причин порушення ефективної перфузії міокарда може бути феномен звивистості ВА.

За даними ангіографії, цей феномен виявляють у пацієнтів різних популяційних груп з частотою від 9,2 до 42,7\% [2 - 4], проте, протягом тривалого часу вважали незначущою ангіографічною знахідкою і у більшості спостережень асоціювали з гіпертонічною хворобою $[1,2,5]$. Результати експериментальних та клінічних досліджень дають вагомі підстави вважати, що зміни конфігурації ВА здатні впливати на ефективність перфузії міокарда $[4,6]$ та виникнення клінічних проявів ішеміі [6 - 8]. Проте, в діагностиці IXC конфігурацію ВА часто не беруть до уваги, оскільки феномен звивистості ВА ще не відображений в сучасній номенклатурі захворювань людини.

Метою дослідження було вивчення ролі звивистої конфігурації ВА в порушенні коронарного кровообігу.

\section{МАТЕРІАЛИ I МЕТОДИ ДОСЛІДЖЕННЯ}

Робота виконана $з$ дотриманням сучасних біоетичних норм. У дослідження включені 1404 пацієнта ві- ком від 26 до 88 років 3 клінічними ознаками IXC, в тому числі 76,1\% чоловіків та 23,9\% - жінок. За даними КВГ, звивистість ВА виявлена у 588 пацієнтів, у 816 пацієнтів змін конфігурації ВА не було.

Залежно від наявності звивистості, атеросклеротичного ураження ВА та ступеня його вираженості виділені чотири групи пацієнтів. У 252 пацієнтів (1-ша група) виявлено звивистість ВА без ангіографічних ознак атеросклеротичного ураження стінки судин; у 92 пацієнтів (2-га група) - звивистість ВА з їх стенозом до 50\% діаметра просвіту; у 244 пацієнтів (3-тя група) - звивистість ВА 3 стенозом понад 50\% діаметра їх просвіту; у 816 пацієнтів (4-та група) без змін кофігурації ВА з стенозом понад 50\% діаметра просвіту судин.

Проведене обстеження пацієнтів з використанням загальноклінічних методів, електрокардіографіï, ЕХО-КГ, велоергометрії, КВГ, стресВЕХО-КГ.

Звивистими вважали ВА з трьома і більше вигинами 3 величиною деформації відносно прямолінійної осі $45^{\circ}$ і більше, визначених у систолу й діастолу $[2,3,6]$. За іншим методом для визначення звивистості судини використовували кут між двома дотичними до проксимального та дистального відводу з максимальною величиною їх нахилу по відношенню до прямолінійної осі, проведеної вздовж основної артерії [4, 9].

Значущість отриманих результатів визначали з використанням методів статистичного аналізу за програмоюи SPSS 16.0 for Windows.

\section{РЕЗУЛЬТАТИ}

В анамнезі у 98\% пацієнтів з звивистими ВА були відомості про типовий для IXC больовий синдром, що обмежувало іх фізичну активність. Аналіз клінічних даних свідчив про наявність у пацієнтів 1-ї та 2-ї груп без гемодинамічно значущого AC ВА стенокардії напруження $(\mathrm{CH})$ $2-4$ функціонального класу (ФК) та хронічної недостатності кровообігу (ХНК, див. таблицю).

Крім того, за даними анамнезу, деякі пацієнти перенесли гостре порушення коронарного кровообігу, в 1-й групі - 60, у 2-й групі - 20, в 3-й групі - 148, у 4-й групі - 476. При цьому, статистично значущих розбіжностей за частотою виникнення гострого інфаркту міокарда не було між 1-ю і 2-ю та 3-ю і 4-ю групами. Водночас, у пацієнтів без гемодинамічно значущого атеросклеротичного ураження ВА встановлені статистично значущі розбіжності за частотою виникнення гострого порушення коронарного кровообігу порівняно з такою у пацієнтів 3-ї та 4-ї груп $\left(\chi^{2}=132,3 ; \mathrm{p}<0,005\right)$.

3 метою оцінки стану коронарного кровообігу та його резервів у пацієнтів 1-ї групи проведені проби з дозованим фізичним навантаженням і стрес-ВЕХО-КГ. За результатами цієї проби, проведеної у 56 пацієнтів без стенозуючих змін ВА, у 54\% 3 них виявлені ознаки порушення перфузії міокарда. Результати стресBEXО-КГ з фармакологічним навантаженням свідчили про наявність у 57\% пацієнтів ознак ішемії міокарда.

При порівнянні частоти виникнення ознак ішеміі міокарда за даними електрокардіографії у пацієнтів 1-ї та 2-ї груп встановлені статистично значущі розбіжності (відповідно у 49,2 та 82,6\%, p < 0,001, $\chi^{2}$ $=30,9$ ).

3 метою оцінки впливу звивистої BA на коронарну гемодинаміку за умови наявності гемодинамічно значущих атеросклеротичних змін судин пацієнтам 3-ї та 4-ї груп проведені ЕХО-КГ та КВГ. За даними ЕХОКГ, у пацієнтів 3-їгрупи спостерігали більшу частоту утворення аневризми лівого шлуночка порівняно 3 та- 
кою у пацієнтів 4-ї групи (відповідно у 16,4 i 9,0\%; p < 0,001, $\left.\chi^{2}=11,39\right) .3$ результатами ЕХО-КГ узгоджені дані КВГ щодо частоти виникнення аневризми лівого шлуночка, що в 3-й групі становила 21,0\%, в 4-й групі $13,0 \%\left(\mathrm{p}<0,001, \chi^{2}=10,98\right)$.

\section{ОБГОВОРЕННЯ}

Звивистість ВА є феноменом, що досить часто виявляють за даними КВГ. Його роль у виникненні порушень коронарної гемодинаміки обговорюється, що зумовлене невеликою кількістю експериментальних та клінічних досліджень, спрямованих на іiі виявлення. Проте, аналіз даних літератури та результатів нашого дослідження свідчить про вплив звивистої конфігурації ВА на коронарний кровообіг, адаптивні можливості міокарда та частоту виникнення судинних катастроф.

В нашому дослідженні встановлено, що у пацієнтів за звивистості BA, незалежно від наявності й тяжкості коронарного АC, відзначене погіршення якості життя. Навіть за сприятливого загального прогнозу це зумовлене обмеженням фізичної активності внаслідок больового синдрому. Його поява у пацієнтів за звивистої конфігурації ВА на тлі відсутності ознак атеросклеротичного ураження судин свідчить про обмеження діапазону адаптивних можливостей коронарного русла. Це підтверджує також поява у пацієнтів 1-ї та 2-ї груп клінічних ознак ХНК. За загальноприйнятими уявленнями, гемодинамічної значущості атеросклеротичні зміни набувають за умови стенозу понад 50\% діаметра просвіту судини. Тому зрозумілими є статистично значущі розбіжності у 1-й і 2-й, 1-й і 4-й, 2-й i 3-й, та 2-й і 4-й групах. Водночас, необхідно звернути увагу на відомості в анамнезі пацієнтів за наявності звивистості ВА (1-ша група) гострого порушення коронарного кровообігу, частота якого становила 23\%.
Опосередковано ці дані дають підстави припускати значущість гемодинамічних порушень перфузіі міокарда за наявності аномалій конфігурації ВА. Таке припущення підтверджують і результати стресBEXO-КГ, за наявності звивистості BA зменшується ефективність перфузії міокарда при підвищенні його функціонального навантаження.

Окрему увагу привертають дані анамнезу щодо частоти виникнення судинних катастроф в 2-й і 4-й групах, результати електрокардіографії пацієнтів 1-ї та 2-ї груп, а також результати ЕХО-КГ та КВГ у пацієнтів 3-ї та 4-ї груп. Поява статистично значущих розбіжностей частоти виникнення ознак ішемії міокарда у пацієнтів 1-ї та 2-ї груп за даними електрокардіографії може свідчити про погіршення перфузії міокарда за наявності звивистих ВА за умови приєднання навіть гемодинамічно незначущих атеросклеротичних змін стінки судин. Наведені дані свідчать про неоднозначність прогнозу перебігу IXC, не ускладненої гемодинамічно значущим атеросклеротичним ураженням стінки судин, за наявності звивистої конфігурації ВА. Водночас, відсутність таких розбіжностей частоти виникнення судинних катастроф опосередковано свідчить про збереження провідної ролі звивистості ВА в порушенні коронарної гемодинаміки за відсутності гемодинамічно значущого АС ВА. Це має привернути увагу кардіологів до такої аномалії конфігурації ВА, потребує диспансерного спостереження пацієнтів з звивистою конфігурацією ВА та застосування заходів вторинної профілактики IXС. Отримані результати дають підстави вважати, що приєднання до звивистості ВА гемодинамічно незначущого АC BA (стеноз менше 50\% просвіту судини) ускладнює перебіг IXC.

3 огляду на дані літератури про роль звивистості ВА як одного з факторів ризику виникнення АС стінки судин [6, 10, 11], слід очікувати несприятливого прогнозу перебігу IXC у пацієнтів за звивистості ВА. Про звивистість ВА як додатковий фактор погіршення коронарної гемодинаміки свідчать результати ЕХOКГ та КВГ, з виявленням погіршення функціонального стану міокарда лівого шлуночка при приєднанні АС до звивистості ВА. Результати досліджень гемодинамічного значення звивистості ВА свідчать про зменшення ролі такої аномалії конфігурації як фактору формування коронарної недостатності у пацієнтів за стенозуючого АС ВА, чим можна пояснити недооцінену роль звивистості ВА у виникненні IXC $[12,13]$. Так, в нашому дослідженні виявлена подібність частоти виникнення судинних катастроф у пацієнтів 3-ї та 4-ї груп на тлі статистично значущого збільшення частоти гострого порушення коронарного кровообігу в кожній 3 цих груп порівняно з такою у хворих 1-ї групи. Отримані результати узгоджуються 3 припущенням про втрату провідного значення конфігурації коронарного русла при приєднанні гемодинамічно значущого AC BA.

\section{вИсновки}

1. Результати дослідження дають підстави вважати, що зміни конфігурації ВА за відсутності гемодинамічно значущого атеросклеротичного ураження стінки судин здатні спричиняти ішемію міокарда і клінічні ознаки IXC.

2. Звивистість ВА $є$ фактором, здатним спричинити порушення перфузії міокарда, а наявність такої аномалії конфігурації коронарного русла створює підгрунтя для несприятливого прогнозу перебігу IXC незалежно від наявності АC BA.

3. Рання діагностика IXC має передбачати як наявність і ступінь атеросклеротичних змін ВА, так і особливості їх конфігурації.

\section{REFERENCES}

1. Marzilli M, Merz CN, Boden WE, Bonow RO, Capozza PG, Chilian WM, et al. Obstructive coronary atherosclerosis and ischemic heart disease. J Am Coll Cardiol. 2012 Sep 11;60(11):951-6.

2. Li Y, Shen C, Ji Y, Feng Y, Ma G, Liu N. Clinical implication of coronary tortuosity in patients with coronary artery disease. PLoSOne. 2011 Aug 31;6(8):e24232. doi:10.1371/journal.pone.0024232.

3. Groves SS, Jain AC, Warden BE, Gharib W, Beto RJ. Severe coronary tortuosity and the relationship to significant coronary artery disease. W V Med J. 2009 Jul-Aug;105(4):14-7.
4. Li Y, Liu NF, Gu ZZ, Chen Y, Lu J, Feng Y, et al. Coronary tortuosity is associated with reversible myocardial perfusion defects in patients without coronary artery disease. Chin Med J (Engl). 2012 Oct;125(19):3581-3.

5. Han HC. Twisted blood vessels: symptoms, etiology and biomechanical mechanisms. J Vasc Res. 2012;49(3):185-97.

6. Zegers ES, Meursing BTJ, Zegers EB, Oude Ophuis AJM. Coronary tortuosity: a long and winding road. Neth Heart J. 2007 May;15(5):191-5. 
7. Xie $\mathrm{X}$, Wang $\mathrm{Y}$, Zhou $\mathrm{H}$. Impact of coronary tortuosity on the coronary blood flow: a 3D computational study. J Biomech. $2013 \mathrm{Ju}$ 26;46(11):1833-41.

8. Xie X, Wang Y, Zhu H, Zhou H, Zhou J. Impact of coronary tortuosity on coronary blood supply: a patient - specific study. PLoSOne. 2013 May 17;8(5):e64564. doi:10.1371/journal.pone.0064564.

9. Li Y, Shi Z, Cai Y, Feng Y, Ma G, Shen C, et al. Impact of coronary tortuosity on coronary pressure: numerical simulation study. PLoSOne. 2012 Aug 14; $7:$ e42558.

10. Demirbag RR, Yilmaz R. Effects of the shape of the coronary arteries on the presence, extent, and severity of the disease. Heart Vessels. 2005 Sep;20(5):224-9.
11. Chumakova GA, Podkovyrkin VA. Klinicheskoe znachenie patologicheskoj izvitosti koronarnyh arterij. Serdce. 2010;9(2(52)):1724-8. [In Russian].

12. Lebedeva EO. Tortuosity of Coronary Arteries - Individual Factor of Ishemic Heart Disease. Visnyk sertsevo-sudynnoi khirurhii. 2014;22:187-95. Available from: http://nbuv.gov.ua/UJRN/ shnp_2014_22_44. [In Ukrainian].

13. Lebedeva EO, Lazoryshynets VV, Beshliaga VM, Grusha MM. Features diagnosis of ischemic heart disease is caused by tortuosity of coronary arteries. Likarska Sprava. 2015;1-2:38-43. Available from: https://www.ncbi.nlm.nih.gov/pubmed/26118025. [In Ukrainian]. 